\title{
POST-MODERNISM, ALLEGORY, AND HERMENEUTICS IN BRAZIL
}

\author{
Bruce Krajewski, award winner
}

Postmodernism tends to substitute enactment for interpretation-a rhetorical approach for the acknowledgement of history-tends to project a two-dimensional world in which line is freed from contour; narrative movement is lateral rather than progressive; figures, even objects are not depicted. . . Postmodernism describes a sensibility a feeling for innovation, for experiment with conventional ways of framing experience so that it is at once removed from recognizable relationships and from the locations in which they exist. This movement is variously informed by a skeptical attitude toward illusion, toward a recognizable psychology of human relationships, and toward coherence of any sequence of actions.

-Stanley Trachtenberg,

The Postmodern Moment

Where everything is bad it must be good to know the worst. -F. H. Bradley

The almost insoluble task is to let neither the power of others, nor our own powerlessness stupefy us.

- Theodor Adorno, Minima Moralia

THIS ESSAY Is a version of a response to a question that Brazil poses: What does it mean to try to understand that which insists on being un-understandable, or aporetic, where aporetic means not that no passages of understanding can be found, but that one is faced with a hundred roads diverging in a tangled wood-an invitation to dispersion?

For the hermeneuticist, aporia are invitations to possible insight. While some see aporetic texts as sources of confusion and bewilderment, a hermeneuticist like Gadamer views confusion and bewilderment as nascent stages on the way to understanding and selfunderstanding. Conundrums and puzzles lead us to think. Gadamer writes, "It is invariably true that when we see something we must think of something in order to see anything." A text's or a person's or a situation's resistance to interpretation provokes, but Gadamer does 
not take this provocation as a belligerent act, rather as a condition of life, a life in which "we proceed constantly through the coexistence of past and future," through the familiar and the strange. "The essence of spirit lies in the ability to move within the horizon of an open future and an unrepeatable past."

A meeting with something or someone aporetic calls us to do something. Of course, some critics will say an interpretation of the different constitutes a form of co-option or assimilation that wipes out difference. However, Gadamer's discussion of our experience with strangeness-particularly with art-insists on "allowing what is to be." 3 We must allow the work of art, the strangeness (whatever form it might take), to speak to us, and "we must realize that every work of art only begins to speak when we have already learned to decipher and read it."4 Strangeness and otherness take on meaning in relation to our ability to take it upon ourselves to produce a shared community of meaning.

My task here with Brazil involves producing possible meanings, though not just any possible meanings, but ones that will develop into a certain position and that will have at least some empirical grounding. In this essay on Brazil, I want to concentrate on possible readings of the film, on meanings for the film, using as much material evidence as possible, while leaving aside the cancelling-out function that de Man mentions. I am appropriating Brazil to make it speak to the present debates about postmodernism, and I do not feign neutrality in these debates.

To call Brazil postmodern is to open myself to attack by those who demand the rigor of definition, because what is to be called "postmodern" is still under debate. Postmodernism has yet to petrify, even though many are ready to label it regressive (Habermas, Jameson), and just as many are prepared to call it "progressive" (Rapaport, Ulmer). The practices of postmodernism are diverse (and perhaps diversionary). Postmodernism refers to a multiplicity of cultural practices chracterized by such things as collage, hybridization, distortion of scale, pastiche, and unreadability. More generally, postmodernism might be called the New Rococo. Etymologically, rococo is a French Enlightenment word that means the fanciful alteration of rocaille shellwork. As its critics stress, this etymology presents a major problem in postmodernism, that is, that postmodernism functions as a shell without any substance, that the postmodern is but a play of surfaces, like a Hollywood set composed entirely of facades, or like the hydrodynamics of a soap bubble. Critics might call it ornamentation 
without foundation, without purpose. The postmodern shell covers a void. ${ }^{5}$

Although Post-Modernism is used in a non-architectural context as early as 1938 by Arnold Toynbee, postmodernism comes into its own through architecture, and the postmodern movement in architecture becomes associated with architects like Gae Aulenti, Robert Venturi, Charles Jencks, and Paolo Portoghesi. The beginnings of PostModernism in architecture are quite different from the postmodernism Habermas or Jameson talk about. For instance, Venturi's Complexity and Contradiction in Architecture (1966) suggests not ahistoricism, but historical awareness, not incoherence, but intricacy and ambiguity. Venturi reacts against Modernism and its "clean," "straightforward," "articulated," "pure" structures. Venturi says, "I am for messy vitality over obvious unity. I include the non sequitur and proclaim the duality." 6 Still, these non sequiturs and dualities are not meant to banish readability or truth. "A valid architecture," he says, "evokes many levels of meaning and combinations of focus: its space and its elements become readable and workable in several ways at once." In this way, Venturi sounds much like Paul Ricoeur, who in Interpretation Theory says that metaphors and complexities within a sentence do not undo meaning, but offer a reader a surplus of meaning. In Architecture Today, Charles Jencks echoes the notion of surplus meaning:

A Post-Modern building is double coded-part Modern and part something else: vernacular, revivalist, local, commercial, metaphorical, or contextual. In several important instances it is also double coded in the sense that it seeks to speak on two levels at once: to a concerned minority of architects, an elite who recognize the subtle distinctions of a fast-changing language, and to the inhabitants, users, or passersby, who want only to understand and enjoy it. ${ }^{8}$

The use of language in Jencks's description suggests what could be called a rhetorical architecture, for it is concerned with context and audience, with delighting or persuading that audience, much in the manner of a sophist trying to win over a crowd. This is the sort of architecture that commands the attention of those capable of being initiated into what is hidden, or double-coded, those who want to see more. The complexity of the architecture teaches the inhabitants that there is something more to be understood.

The rhetorical side of early postmodern architecture, and the writings that accompany that architecture, emerges most clearly in the work of Paolo Portoghesi, who, in what Jencks calls "his most creative book, The Rome of Borromini: Architecture as a Language (1967), showed that Borromini used a highly rhetorical set of figures and complex language because he was strongly motivated to communicate specific religious and structural ideas to a wide audience and to sustain interest

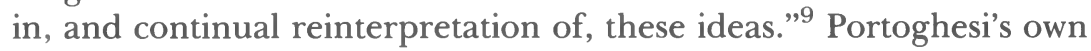


work and writings reflect his interest in Borromini, in the value of communication and continual interpretation, which shows an awareness of Gadamer's point in Truth and Method that we are always understanding differently. The pleroma, the fullness of time, will bring out the plethora of meaning.

Unlike some postmodernists, Portoghesi does not wish to put history and tradition under erasure. In fact, the theme of the 1980 Venice Biennale (Portoghesi was the organizer of the architecture section of the Biennale), where postmodern architecture came into public prominence, was "The Presence of the Past." John Blatteau elaborated on the theme in his architectural self-portrait for the exhibition: "It is again possible to learn from tradition and to connect one's work with the fine and beautiful works of the past." ${ }^{10}$ Clearly, these architects listen to what has come down from the past, and the hope is to make the past present again.

When postmodernism leaves architecture and enters the discourse of literary criticism and philosophy, it takes a nasty negative turn and becomes a conglomerative carnival of cacophony, assimilating extremely heterogeneous modes of stylisitic expression, but often this expression aims not to press out, or make its way out to others; instead, postmodernist expression in its non-architectural context seeks to excommunicate, to cut people off from a common base of understanding. Not to understand becomes one of the goals of postmodernism, or, at least, postmodernists like to frustrate or "problematize" understanding. Derrida's method of using paronomasia or repetition in his works serves as an example of this postmodernist strategy to move away from any grounding-in other words, to float.

The image of floating, or flying, appears not only in Brazil, but also in Herman Rapaport's discussion of Lauri Anderson's United States, specifically a piece called "Blue Pacific." The speaker, Blue Pacific, "is a surface, an atmosphere of modulating moods.... She is a tourist whose state is an undercommitedness of consciousness.... She appears to sleep even while awake. 'Blue Pacific' isn't a name at all but just the topos associated with a flotation of voicings." "For postmodernists, this state of floating, or undercommitedness, signifies freedom, an escape from hegemony. For Rapaport, Anderson's performance in United States "is releasing or activating resonances which undermine . . . hegemony's efficacy as a stable equilibrium in which the power of the elite culture appears natural." ${ }^{12}$ In "Blue Pacific," "character itself is never quite established, since the performer has successfully 'submerged' herself in a neutrality of doing." 13 The images of flotation and submersion appear to contradict, but actually complement each other in the context of neutrality, for both images 
indicate a movement away from any ground. Those who float or who are submerged do not take up any position in the sense of a stand. The acceptance of neutrality in Rapaport's version of postmodernism turns against rhetoric, against peitho. To be persuaded of somethingthe design the rhetorician has on an audience-is to take a position (perhaps even a dance position, and human dance requires a ground; one submits to the hegemony of gravity).

From another perspective, postmodernism's attraction to the performative could be seen as a pre-rhetorical, or proto-rhetorical, moment, as one of the few ways expression can make its way in the world in the face of a crushing hegemony. According to one account of the "origin" of rhetoric, Sicily in 467-466 B.C. was ruled by two tyrants, Gelon and Hieron.

It is said that the tyrants indulged their savagery to the extent of forbidding the Syracusans to utter any sound at all but to signify what was appropriate by means of their feet, hands, and eyes whenever one of them was in need. It was in this way, they say, that dance-pantomine [orchestike] had its beginnings. Because the Syracusans had been cut off from speech, they contrived to explain their business with gestures [or dance-figures: schemansi] ${ }^{14}$ [Farenga is quoting from Prolegomenon sylloge, ed. Hugo Rabe (Leipzig: Teubner, 1931)].

As part of the commentary on this passage, Vincent Farenga says, "Rhetoric is not, then, innate to human society, but it nonetheless comes to the citizens as something they need to regain their selfpresence, their identity or true nature." 15

Dance, which one might also see as a form of play, links up with identity, presence, and ground. It is play in the way Gadamer speaks of it, in the way he appeals to the original meaning of play (Spiel) as dance. "The movement which is play," Gadamer says, "has no goal which brings it to an end; rather it renews itself in constant repetition." 16 This conception of play and repetition differs greatly from that of postmodernists like Derrida, who employs repetition to reveal the negativity in play. Gadamer too notes that subjectivity dissolves in play, for it is play playing, but the play leads to the player's reconciliation with self: "That which detaches [the player] from everything also gives him back the whole of his being."17

From the side of postmodernism, play empties being. Despite feeling trapped and tyrannized, postmodernists still dance. On to the stage comes the dancing Derrida, who wishes to expunge presence, identity, and truth through a certain kind of play-frivolity. "Philosophical style congenitally leads to frivolity," he writes. "If philosophical writing is frivolous, that is because the philosopher cannot fulfill his statements. He knows nothing, he has nothing to say, and he complicates, subtilizes, refines the stylistic effects to mask his ignorance [masks will become important in the discussion of Brazil]. Thus 
he misleads, pays change out of the essential emptiness of his discourse. ${ }^{18}$ Hans Blumenberg understands the relationship between this negativity and frivolity, and his perspective unsettles Derrida's playfulness:

One who discovers the law of increasing misery sees everything driving toward the point at which the only thing left is for everything to become different [differance].

Frivolity is only a weak derivative of all this, a means of anthropomorphic relaxation of tension vis-a-vis myth: One can do this, or say that, without being struck by lightning. It is the first stage of 'Enlightenment' satire, of rhetorical secularization as a stylistic technique employed by a spirit that is not yet confident of its [or his] enlightened status. ${ }^{19}$

Derrida claims that frivolity begins its work in repetition, "in the fissure which, separating two repetitions, rends repetition in two. The repetition of the idea, the identity of ideas is not frivolous. Identity in words is frivolous." 20 The repetition of words characterizes Derrida's writing, for he wishes to show how supplementarity is at work. Repeating a word places it in a new context, giving it a different sense. The infinity of contexts in which words appear eliminates the possibility of words having univocal meanings, or what might be called an identity. This is what Derrida calls iterability. Part of Derrida's project involves exacerbating this iterability to produce undecidability. He empties language by overfilling it with frivolity, by decorating the margins to make a kind of illuminated manuscript that gives off no light, only lightness. However, this frivolity is not to be taken frivolously. Derrida does willful violence with deconstruction, for he uses repetition in its etymological sense, i.e. to attack again. Then again, one might see, as Richard Bernstein has begun to, that even deconstruction is done in the name of something. ${ }^{21}$

It becomes clear that Gadamer's notion of play and Derrida's idea of play, or frivolity, are different. One of the points that distinguishes Gadamer's talk of play and postmodern play is that Gadamer's play looks like children's play. In Truth and Method, for instance, Gadamer talks about the children's game of "Tinker, Tailor, Soldier, Sailor," and the way children play motor-cars. ${ }^{22}$ On the other hand, postmodern play is sophisticated adult play that often isn't play at all, but overly self-conscious self-consciousness, which continually denies itself. It plays off a self-lesser-than-thou attitude. And this is why I choose to stay with the side of rhetoric rather than postmodernism, because rhetoric signals a return to trust, wobbly as that trust might be. Rhetoric makes its full appearance in the "original" story of rhetoric with the entrance of Korax, who, after the Syracusans overthrow the tyrants, steps forward when everyone is talking and persuades the crowd to be silent. Korax transforms democratic noise into silence again, but this silence comes about through peitho rather 
than bia, consent rather than compulsion. Gerald Bruns sums up this account of rhetoric's beginnings by saying, "The whole lesson of rhetoric, it turns out, is not how to speak, but how to render others speechless. .. . Rhetoric is the recuperation of tyranny by means of language." ${ }^{23}$ Rhetoric too has its dark side, which must be acknowledged and understood.

II

One of postmodernism's facets that requires attention, in relation to Brazil, is the turn toward allegory. Long disparaged, allegory reemerges as an important part of postmodernism, without its Christian cross to bear, without much weight at all in the case of Brazil. In a two-part article, Craig Owens speaks of an "allegorical impulse" in postmodernism. ${ }^{24}$ Why this impulse? In "Notes on the Reemergence of Allegory," Stephen Melville says we live in "an age whose relation to its past has become problematic. ... [This age] will be led to find and guarantee itself and its work through detour and delay-works and devices of indirection." ${ }^{25}$ Allegory is indirect discourse, a speaking otherwise. As Gadamer says, "Allegory originally belonged to the sphere of talk, of the logos, and is therefore a rhetorical or hermeneutical figure. Instead of what is actually meant, something else, more tangible, is said, but in such a way as to suggest the other." ${ }^{26}$ In other words, allegory points to a condition in which what needs to be said cannot be said directly for some reason. Allegory, as Bruns figures it, protects us. The truth cannot be viewed directly, so allegory, or "the veil of words," mediates the truth. Without the curtain or the veil, we would be unable to see anything at all because the light would blind us. Bruns writes:

No doubt it is the job of understanding to penetrate [sic] the veil of words and to disclose what is hidden, but in fact the understanding cannot accomplish the task quite in this way. He who understands something is usually less knowledgeable than resourceful. $\mathrm{He}$ is able to regard what is hidden by constructing a version of it or by construing a meaning of what is not evident-but throughout all of his artfulness the veil remains intact. ${ }^{27}$

The reader does not pass over the surface of the allegory, for the surface gives what is to be understood. It is not surprising then that the surfaces of allegories are detailed, ornamented, specific in a very odd way since the extreme specificity provides clues to general insights, to larger cultural associations. In its simplistic form, allegory toys with generality, as in the case of the medieval play Everyman in which the characters' names reveal their roles in the drama. In the modern and postmodern periods, allegories tend to be less like Everyman and more like Kafka's stories, say "In the Penal Colony." Although this modernist text assigns characters general names like the 
Officer and the Explorer (making it similar to the Everyman allegory), Kafka includes a far more intricate allegorical surface in, for example, his complex description of the machine used to punish. In the tale, the Officer tries to aid the Explorer in understanding the machine by showing him the plans for the device. "The Explorer would have liked to say something appreciative, but all he could see was a labyrinth of lines crossing and re-crossing each other, which covered the paper so thickly that it was difficult to discern the blank spaces between them." 28 Despite the opacity of the text before him, the Explorer realizes that there is something to be understood, but as an outsider, as one who is uninitiated, he is not prepared to understand. For the moment then, he is unable to read what is going on, so he is stopped at the surface.

The question I want to ask about Brazil is related to the Explorer's dilemma: What happens to understanding when all is surface? What happens when a veil conceals nothing?

Like Kafka's allegories, Brazil presents a detailed, elaborate surface. At the beginning of the film, the time and the approximate historical period appear on the screen. It is 8:49 p.m.; the action takes place "Somewhere in the 20th Century." These two items reveal themselves to be pseudo-details, allegorical touches without allegorical import. The time constitutes a needlessly precise detail; on the other hand, the tag "Somewhere in the 20th Century" constitutes an overly generalized piece of information, like the Everyman title. The film quickly moves to contradict this generality, however, for the film shows the viewer a chronologically specific world of cars, computers, televisions, microwave ovens - a world quite familiar to the middle class of advanced industrial society. The effect is something like the Russian formalist notion of ostrananie, the device of making something strange in order that the viewer or reader might see the familiar as if for the first time. For instance, the computers in the film look like the personal computers now in use, except the keyboards have the kind of keys one would find on an old manual typewriter, and the monitor, instead of being a box like a television set, is more like a thick piece of glass. The disguising, or the allegorizing here, is of the slimmest sort, so that the boundaries between reality and allegory often dissolve. In other words, reality does not seem to buttress the disguise, as if there were no face to support the mask.

"Allegory," says Craig Owens, "is consistently attracted to the fragmentary, the imperfect, the incomplete-an affinity which finds its most comprehensive expression in the ruin. ..."29 Brazil's ruin is Sam Lowry. He is fragmented, imperfect, and incomplete-Postmodern Man. "Ruin" is from the Latin verb "to fall," and this is what 
happens to Sam from the outset: His course is steadily downward. One can even find the word "low" in his name.

The first-time viewers see Sam, we do not see Sam, but rather his heroic vision of himself in a dream. Also, Sam's absence is accented from the beginning of the film. At the Department of Records where Sam works, Mr. Kurtzmann (another of those allegory-like names), his boss, steps out onto a platform overlooking the workers, and Kurtzmann calls out, "Has anybody seen Sam Lowry?" No response. No one, not even the viewer, has seen Sam. Sam is not noticeable, as is made clear later in a brief chat Sam engages in with Jack Lint, a friend, as the two pass in the huge building that houses the Department of Records:

Jack: If I'm worried about anyone, Sam, it's you. Sam, whatever happened to you? (Jack touches Sam's topcoat).

Jack talks about Sam in the past tense. It is as if Sam does not exist, or at least possesses no identity. (Part of his identity is tied into his clothing, another surface feature, an item which becomes important later in the film when Sam "rescues" Jill from the state police). Later in the same conversation, Jack comments on Sam's job at the Department of Records, telling him that it is impossible to get noticed in Sam's present job. Sam's response is "I know. Wonderful, marvelous, perfect." The triadic adjective phrase is an echo of the words Jack has used moments earlier. Apparently, Sam is incapable of formulating his own phrases, but this does not bother him. He revels in it, prefering to be transparent. Sam wants to be an absence (like his father who is absent from the film), so that he can be unreadable. There is no text-ure to absence. Despite Jack's encouragement, Sam refuses to re-present himself, relinquishing that responsibility to whom? An important question here is whether there can be any such thing as the understanding of that which withholds itself or remains hidden. Given what Sam says, he does not wish to understand or to be understood, an act which calls for the presence of others. Sam wishes to withhold his responsibility for things that go on in the world around him, as he demonstrates when he tries to defend himself against Mrs. Terrain, who proposes in an accusatory tone that Sam do something about the terrorist bombings that have been going on for 13 years. Sam's response to Mrs. Terrain is that the bombings are not the responsibility of his department. From Sam's point of view, he is relieved of his obligations to society by his lack of position. In a society so specialized, so fragmented, Sam's realm of control, of responsibility, is quite small. He cannot even cope with basic malfunctions in his own apartment. More generally, Brazil shows us a society without a leader, someone to take responsibility for a large range of matters. 
Unlike 1984, Brazil never shows us Big Brother, only brothers. We see Central Services, but no Center. Sam lives in an ennucleated society, which might explain why the terrorist bombings prove ineffective. There is no head to kill, and the appendages of the bureaucracy seem to regenerate.

The first time the viewer sees Sam, the viewer does not see Sam. We get caught up in the pool, or whirlpool, of Narcissus, because the viewer's first vision of Sam is Sam's vision of himself. The viewer sees Sam's construction of himself in a dream in which Sam imagines himself to be an Icarus-like hero, a mighty, winged man flying above the clouds. To know the story of Icarus is to know that people who fancy themselves to be Icarus-like are in for a bad fall, or at least a return to Mother earth. In Sam's case, the fall becomes a return to his mother and things associated with his mother, like the exotic. For example, his mother has a leopard rug in her home, and wears an upside down boot covered in leopard skin as a hat. (This hat symbolizes the inversion Sam's mother desires. She wants to turn back time, to regain her youth through a face-lift). The exoticism of Ida Lowry can be tied to the film's title as well, since the country Brazil reminds one of the Amazon and the jungle. As Sam returns to his mother's abode at the end of the film-he goes there with Jill seeking refuge from the police, and he is about to have intercourse with Jill in his mother's bed when the police storm into the room-he also returns to "Brazil," the song, for comfort. In fact, the very words of the 1939 song include the notion of return. In the film, return becomes synonymous with escape. Icarus too ascended to escape a labyrinth, a world that seemed to have no exit. ${ }^{30}$ For the moment, the stress of the Icarus image is on the letter "I," hence the pronoun, i.e. on Sam's narcissistic tendencies, and what becomes of his obsessional desire.

In Sam's dream, a sound, a cry, alters the flight path of Sam/Icarus, the amalgam of Sam and the Icarus-like hero in his dream. The cry is a woman's voice calling out "Sam!" Sam/Icarus' direction changes with the recognition of his name. By attending to this call, Sam finds a veiled woman who is also hovering about, and Sam/Icarus flies over to her to kiss her through the veil. He kisses the imaginary mouth that utters his name.

Another call, this one from Mr. Kurtzmann reminding him that he is absent from work, interrupts Sam's dream. Once again, he responds to a call for his presence, his attention.

When we return to Sam's dream, a new figure enters, a large, Samurai-like creature, who, from Sam/Icarus' perspective, has had something to do with the veiled woman being caged. A passage from Adorno's Minima Moralia makes some sense of this great, enigmatic 
Samurai figure. Adorno writes, "Pieces of news, like the repulsive humoristic craze for the Loch Ness Monster and the King Kong film, are collective projections of the monstrous total State. People prepare themselves for its terror by familiarizing themselves with gigantic images." ${ }^{11}$ As Sam/Icarus finds out when he removes the Samurai's mask: The Samurai is Sam. In an essay, "The Festive Character of Theater," Gadamer writes:

It is the unsettling gaze of the mask that is pure attention, all surface with nothing behind it, and thus pure expression. It is the rigidity of the puppet on a string that nevertheless dances, the alien shock that shakes our comfortable bourgeois self-confidence and puts at risk the reality in which we feel secure. Here we no longer come to self-knowledge within the sovereign realm of our inwardness. We recognize ourselves as the plaything of the mighty, supra-personal forces that condition our being. ${ }^{32}$

Sam is behind this image of the total state, for he is a functionary within it, complicit in a bureaucracy, and feeling guilty. Sam knows that a mistake has been made. Archibald Tuttle, heating engineer, was supposed to be taken into custody, but instead people from the Ministry of Information arrested a Mr. Buttle, who died under questioning. Sam goes to Buttle's family in "Shangrila Towers" to try to give them a check to compensate for their loss, and out of this meeting comes the question, "Where's the body?" Some accounting for the absence of Buttle's body must be made (to establish Buttle's identity), and the question disturbs Sam, even though Sam himself longs to be absent, to be a missing body, one who will not be noticed or questioned.

For Sam, his freedom comes from lack of ambition in his job. However, as far as Sam's mother is concerned, his stagnation in his job is a sign of his immaturity. She tells him, "Sam, it's time for you to grow up and accept responsibility. Your poor father would be appalled at your lack of promotion." Growing up means moving vertically, and verticality is what characterizes the total political state in Brazil. The connection between verticality and power pervades the film. Pauline Kael, in her review of Brazil, notes that "the picture has a weirdly ingenious vertical quality: the camera always seems to be moving up and down, rarely across, and this seems like a violation of nature." ${ }^{33}$ Most of the buildings in the film look like towers, and as I have noted, the Buttle family lives in a place called "Shangrila Towers." Interestingly, Jill Layton, whom Sam thinks is a subversive, first appears in the film in a bathtub. Jill is in a horizontal position that conflicts with the dominant vertical. Her resistance to verticality is reflected in her derisive attitude toward anyone or anything connected with the bureaucracy, e.g. she knocks aside a snoopy machine when she goes to the Department of Records to reclaim Mr. Buttle's 
body.

Mrs. Lowry encourages Sam to move vertically by accepting a promotion Mrs. Lowry has arranged with Deputy Minister Helpmann, who has fond memories of Sam's father. Sam meets the Deputy Minister at a party Mrs. Lowry throws to celebrate her face lift (another concern with the vertical, i.e. lifting sagging things up). Helpmann calls on Sam for assistance in getting to the bathroom, since he is confined to a wheelchair. Sam lifts Helpmann, makes him vertical so that he might use the urinal. Helpmann's inability to get his own body vertical testifies to his impotence. (His name, as in an allegory, tells us something about him: he needs help). During the time that Helpmann and Sam are in the bathroom, Helpmann begins to reminisce about Sam's father, who is absent from the film, "a ghost in the machine," indicating that his presence is still felt despite his absence. In his nostalgia, Helpmann spills some powder on the bathroom sink, and he spells out ERE I AM J H in the powder. ERE I AM J H is an anagram for Jeremiah, the name of Sam's father. The anagram is also a code that operates the elevator that eventually takes Sam to the top of the Ministry of Information. The name Jeremiah can also be linked to the elevator, because Jeremiah is Hebrew for "God will elevate."

Of course, Sam's interest in scaling the vertical, in moving up, is prompted by his desire for Jill Layton, by his desire to keep her horizontal. He wants power over her, as he does in his dream. The desire in his dream and the desire in reality coincide for Sam. To paraphrase Deleuze and Guattari's Anti-Oedipus-desire makes its entry when the question "What does it mean?" cannot be answered, or perhaps even asked. In other words, Sam's inabilities to figure out his own situation, to make sense of the world, lead him to focus his attention on desire. It is important to note that Sam's desire for Jill Layton emerges from a dream. He has an image of a woman in his dream, and this dream-woman appears on a television monitor. ${ }^{34}$ Jill then becomes an obsession for Sam, so that a man who was once indifferent to promotion, at times even hostile to it, now craves to move up, to become more involved in MOI, since he believes that a promotion will allow him to gain more information about her. What he craves, however, is information, not understanding, and this leads him to misunderstand the object of his dream. By the end of the film, Sam's desire for Jill Layton leads him to erase her by taking her off the central computer. In a sense, she then exists only for him, as she does in his dream. She is present for him, but absent from society, or at least from the state's method of accounting for people.

Here I want to introduce an on-the-other-hand, because a herme- 
neuticist recognizes that Being and Not-being are equally and inseparably fundamental. For instance, while Sam's absence is important, he also seems at the same time to be omnipresent. Mr. Kurtzmann is looking for Sam at the beginning of the film; Sam's mother worries about him, as does Jack Lint. He is someone who is on many people's minds, or one might say, Sam is "in the air," as he is literally in his dream. As Jill Layton discovers, Sam is not easily gotten rid of. Jill kicks him out of her cab, but Sam comically clings to the cab, popping up all over the outside of the cab as it speeds along, a scene very similar to one in Raiders of the Lost Ark. He is an annoyance that people cannot shake off. Even at the end of the film, Sam is nettlesome to his tortureres, because they "lose" him-Sam escapes into an imaginary world and hums the theme song of Brazil. Further torture becomes useless. Although Sam withdraws mentally, his body remains, and something must be done with it.

The viewer might read Sam as an embodiment of the film. Sam shows himself to be an empty shell. He might be omnipresent, in a sense, but his presence makes no difference. In a perverse statement, director Terry Gilliam claims that this "empty shell" of a character who hums the theme song is really a hero. Gilliam says Sam "escapes into madness, which I've always considered a reasonable approach to life in certain situations. To me, that's an optimistic ending. Lowry's imagination is still free and alive; they haven't got that. They may have his body, but they don't have his mind."35 "Madness is reason" sounds like the slogan "War is Peace" in 1984. The political implications of such postmodernist "logic" need to be questioned, for it is certainly not optimistic that at the end of the film viewers are left to see that the state bureaucracy triumphs. The mass of people remain subject to a brutal total state, substantially unaffected by all forms of resistance-even terrorism.

Terrorism is a major theme in Brazil. At its most radical, Brazil seems to endorse terrorism. At its most pessimistic, Brazil tells its audience that even terrorism is useless against a bureaucratic state (read: United States). In the first five minutes of the film, a bomb explodes in a store displaying eight television sets. One of the TV sets survives the explosion. Terrorism depends on television's survival. The remaining TV set is tuned to an interview program in which Deputy Minister Helpmann is being questioned about terrorism. Although the bombing campaign is in its 13th year, the Deputy Minister is not taking terrorism seriously. The interviewer asks, "What do you believe is behind this recent increase in terrorist bombing?" Mr. Helpmann replies, "Bad sportsmanship." Obviously, the state does not feel threatened by the bombings. 
The relationship between Sam and Jill Layton is connected to terrorism as well. Part of Sam's attraction to Jill Layton seems to be his assumption that she is part of a terrorist group. (Again, Sam's attraction to the exotic). Jill, as Sam's ideal of beauty, is a terrorist. Vicki Hearne is one writer who recognizes the relationship between terror and beauty. Hearne writes, "To know beauty is to know the loss of beauty and thus full angst in the face of the knowledge of death." 36

Sam transfers his own desires for terrorism onto Jill, as the viewer sees when Sam reaches across and pushes on the accelerator in Jill's truck when Jill and Sam are approaching a police roadblock. After crashing through the roadblock, Sam is jubilant. Resisting the state brings him joy, though he still does not approve of Jill as a terrorist. He believes a Christmas package she is carrying is a bomb. When Jill proposes that Sam open the package to confirm its innocuous contents, Sam refuses. He feigns trust. Throughout the film, there is a repression of terrorism. A bomb goes off while Sam and his mother are having lunch, and no one pays attention to the burned and mutilated bodies, except some of the restaurant workers. A band continues to play in the restaurant, and the waiters put up a partition so that the customers do not make an effort to look. Maurice Blanchot writes about this attitude toward disaster in L'Ecriture du desastre: "The disaster ruins everything, all the while leaving everything intact. It does not touch anyone in particular." ${ }^{37}$ The repetition of terrorism devalues its impact. In fact, in the world of Brazil, terrorism appears to be a "normal" part of life. The traumatic effects of the bombings are absorbed in order to be forgotten. Blanchot says that the disaster is related to forgetfulness. Forgetfulness and withdrawal mark the postmodern scene, at least as it appears in Brazil.

\section{III}

The victory of the state over the people as portrayed in Brazil contradicts the film's references to Eisenstein's work, particularly to October and Battleship Potemkin. Before addressing the political differences between Gilliam's film and Eisenstein's work, I should note the references to Eisenstein's work in Brazil. For example, one of Gilliam's quotations of Eisenstein involves a mask worn by Jack Lint, a character who tortures people for the state. (Brazil tells us that one's worst enemy is one's friend.) The mask, or one very much like it, can be found in the "masks of the gods" montage in October (1928). Also, toward the end of Brazil, when Sam Lowry imagines he is part of Archibald Tuttle's revolutionary forces, Gilliam presents a repeat of Eisenstein's Odessa steps sequence from Battleship Potemkin (1925). ${ }^{38}$

Generally speaking, Eisenstein's films present the viewer with 
images of mass action. Political changes come about through social movement, like the storming of the Winter Palace depicted in October. In Eisenstein's films, the state does not crush the people, nor force them to retreat into their imaginations, as if imagination were the only place left for freedom.

In Brazil, one can find little hope for political change, either in the diegetic space, or in the space of our own society. One of the few hopes lies in Archibald Tuttle, who is apparently still loose in the world of the film, acting as a kind of Robin Hood, or as an outlaw mechanic. Tuttle understands how things fit together. For example, the labyrinthine structure of ubiquitous pipes and hoses frustrates Sam but not Tuttle. For Sam, the "system," if only of pipes and hoses, is out of control, and his attempts at understanding are repeatedly frustrated.

This sort of frustration also characterizes postmodern politics and art, which is one reason I think Brazil serves as an example of postmodernism in its non-architectural context. Not to understand is one of the goals of postmodernism. Postmodernists celebrate incoherence, the uninterpretable. In many ways, Brazil resists interpretation. In Brazil, one can detect anagrams, allusions to other films, allegorical elements, but ultimately one is at great pains to piece the puzzle together, partly because the pieces come from many different puzzles, or, to use another image, the viewer cannot find the key to unlock, say, the end of the film, which takes place in a vast domed structure shaped much like a keyhole, a shape that appears as an important clue.

Brazil could be seen as an example of an anti-hermeneutical work, but here I would stress that to call something uninterpretable is still to understand the work in some way. The Heideggerian "as-structure" of understanding is still at work, for the viewer can see Brazil as a postmodern work. Something completely alien, completely beyond comprehension would be terrifying. We would be in the realm of the Unspeakable.

While many postmodernists have been moving away from dialogue and toward the Unspeakable, Juergen Habermas has been writing in favor of a return to social solidarity and integration, and a repudiation of an anti-hermeneutics campaign. For Habermas, to produce works which are unreadable encourages disjointedness and confusion. Habermas contends that social unity can be achieved with communicative argumentation which supplants more authoritarian and coercive forms of social coordination-he is supporting a return to rhetoric. ${ }^{39}$

A proponent of postmodernism, Jean-Francois Lyotard sets out to refute Habermas, and proposes smashing any idea that supports unity 
of experience. For postmodernists, it is naive to have confidence in the notion of emancipation through social action (Eisenstein). Postmodernists endorse the death of the social, and prefer neutrality to taking sides in social causes, because successful resistance merely substitutes one form of power and oppression for another. Nevertheless, at the the end of the essay, "What Is Postmodernism?" Lyotard uses militaristic language in his diatribe against coherence: "Let us wage war on totality," he writes. "Let us be witnesses to the unpresentable; let us activate the differences and save the honor of the name." ${ }^{40}$ As Felix Guattari sees it, "According to Lyotard we must still be extemely suspicious of the least desire for any serious social action. All values that achieve a consensus, he says, have become old fashioned and questionable." ${ }^{" 1}$ Guatttari refuses to nod to Lyotard's call to war, as do I.

Lyotard would like Brazil, for "Brazil makes you feel that no rational understanding of the world is possible-that all we have is what T.S. Eliot called 'a heap of broken images." "42 In this respect, Brazil is a rocaille shellwork, made from broken images or shells put together like a mosaic, a mosaic filled with bits of information. This point would probably please Lyotard, since at the end of The Postmodern Condition, he urges the opening of data banks to the public in the belief that "Language games would then be games of perfect information at any given moment." ${ }^{3}$ Lyotard's suggestion emerges, in part, from the postmodern paranoia concerning totalizing effects, and exhausting texts-as if such a thing were possible. Gadamer has shown that understanding always requires an endless back-and-forth of a manysided dialogue. For Gadamer, understanding is never finished, because, as creatures in history, we are always understanding differently.

Also, Lyotard confuses the relationship between information and understanding. Give someone who reads only English 50 encyclopedias written in Arabic, and you have increased that person's access to information, but understanding has not improved at all. In "What is Practice?: The Conditions of Social Reason," Gadamer puts the matter this way:

The increase in the degree of information, then, does not necessarily mean a strengthening of social reason. Instead, it seems to me that the real problem lies right here: the threatening loss of identity by people today. The individual in society who feels dependent and helpless in the face of its technically mediated life forms becomes incapable of establishing an identity. ${ }^{44}$

Searches for identity and attempts at abolishing identity propel Brazil, e.g. the Buttle/Tuttle confusion, and Sam's attempt to "delete" Jill Layton from society. Given the immense bureaucratic structures cemented in place in Brazil, people are reduced to functionaries, mere operators of machines. The state and the state's technology subordi- 
nate identity to themselves; human beings can identify themselves only in relation to their positions in institutions or in relation to their attachments to technological devices. It is no coincidence that the acronym for the Ministry of Information is MOI. A decade before Brazil, Gadamer described the situation Terry Gilliam put on film, a world in which, as Gadamer says, "ever fewer people are making the decisions and ever more are manning the apparatus." 45

The bottom line here is, of course, capital, not art, nor postmodernism, though all three are connected. Scheinberg's attempt to make Brazil a happy film for "the all-important teenage category" underscores the political message Hollywood sends out, a postmodern message that endorses floating along in a state of undercommittedness (to use Rapaport's language), but committed to happy endings and to the belief that freedom of the imagination is sufficient in a repressive state (recall Gilliam's claim that Sam is a hero). From the side of hermeneutics, the point is to see Brazil differently-as a film that speaks to present circumstances, circumstances in which effective political dedication is missing, and in which such dedication needs to be renewed. ${ }^{46}$

\section{NOTES}

1 Hans-Georg Gadamer, The Relevance of the Beautiful and Other Essays, trans. Nicholas Walker (Cambridge: Cambridge University Press, 1986), p. 29.

2 Gadamer, p. 10.

3 Gadamer, p. 49.

4 Gadamer, p. 48.

5 Marxist critics in particular have been wary of postmodernism. In "Postmodernism and Consumer Culture," for instance, Fredric Jameson accuses postmodernists of reinforcing the logic of consumer capitalism, and dicusses postmodernism in relation to schizophrenia. See Jameson's article in The Anti-Aesthetic: Essays on Postmodern Culture, ed. Hal Foster (Port Townsend, 1983), pp. 111-125. According to Hal Foster, the absence of History constitutes the postmodern void. He writes, "Does not the relativism of pastiche (its implosion of period signs) erode the very ability to place historical references - to think historically at all? To put it simply, the Postmodern Style of History may in fact signal the disintegration of style and the collapse of history." See Foster's Recodings: Art, Spectacle, Cultural Politics (Port Townsend, 1985).

In language equally as strong as Foster's, Richard Wolin calls postmodernism a "diabolical turn of events," and sees it as a "brave new world of systems theory cybernetics." See his "Modernism and Postmodernism" in Telos (Winter 1984-85), pp. 9-29. An Italian art historian Giulio Carlo Argan, also objects to postmodernism as a kind of "antihistory," since postmodernism indicates "the abandonment of any goal, or design, the lack of all ideological pressure and of any quest for new values." See Argan's "History and Antihistory" in Flash Art 125 (December 1985/January 1986), pp. 54-55.

New German Critique devoted its Fall 1984 issue to the topic "Modernity and Postmodernity." The articles dealing with postmodernism's lack of foundation and lack of purpose include: Fredric Jameson's “The Politics of Theory: Ideological Positions in the Postmodernism Debate," pp. 53-66; Seyla Benhabib, "Epistemologies of Postmo- 
dernism: A Rejoinder to Jean-Francois Lyotard," pp. 103-126; and Gerald Raulet, "From Modernity as One-Way Street to Postmodernity as Dead End," pp. 155-177.

6 Robert Venturi, Complexity and Contradiction in Architecture (New York, 1966), p. 16.

7 Venturi, p. 16.

8 Charles Jencks, Architecture Today (New York, 1982), p. 111.

9 Jencks, pp. 112-113. I think Portoghesi would approve of the rhetorical and hermeneutical turns I give to postmodernism, for he attends to rhetoric and is interested in the dialogical, as is Hans-Georg Gadamer. As Portoghesi says of Borromini, "Borromini . . . considers his profession as a formidable instrument of apprehension. ... He uses every means for speaking with his interlocutor" (p. viii). In the conclusion of the Borromini book, Portoghesi speaks of Borromini searching for liberation from "an autonomous purity that reduced [architecture's] communicative possibilities” (p. 391). Both quotations are from Barbara Luigia La Penta's translation of Portoghesi's The Rome of Borromini (New York, 1968).

10 Paolo Portoghesi, Postmodern: The Architecture of Postindustrial Society (New York, 1983), p. 15. Unlike literary and philosophical postmodernists, Portoghesi writes repeatedly about communication rather than the undermining of discourse. He says, "The Postmodern in architecture can therefore be read overall as a reemergence of archetypes, or as a reintegration of archetectonic conventions, and thus as a premise to the creation of an architecture of communication, an architecture of the image for a civilization of the image" (p. 11).

11 Herman Rapaport, “Can You Say Hello?’: Laurie Anderson's United States,” Theatre Journal 38 (October 1986), p. 350.

12 Rapaport, p. 348.

13 Rapaport, p. 351.

14 Vincent Farenga, "Periphrasis on the Origin of Rhetoric," Modern Language Notes 94 (December 1979), p. 1035.

15 Farenga, p. 1036.

16 Hans-Georg Gadamer, Truth and Method (New York, 1975), p. 93.

17 For a better understanding of Gadamer's view of play, see his chapter "Play as the Clue to Ontological Explanation" in Truth and Method, pp. 91-119.

18 Jacques Derrida, The Archeology of the Frivolous: Reading Condillac, trans. John P. Leavey, Jr. (Pittsburgh, 1980), p. 125.

19 Hans Blumenberg, Work on Myth, trans. Robert M. Wallace (Cambridge: Massachusetts Institute of Technology Press, 1985), p. 17.

20 Derrida, p. 127.

21 Richard Bernstein, "The New Skepticism," lecture delivered at the University of Iowa (March 9, 1987).

22 Gadamer, Truth and Method, p. 97.

23 Gerald Bruns, "Language and Power," Chicago Review (Spring 1984), p. 29.

24 Craig Owens, "The Allegorical Impulse: Toward a Theory of Postmodernism," October 12 (Spring 1980), pp. 67-86, and "The Allegorical Impulse (Part 2)," October 13 (Summer 1980), pp. 59-80. Gregory L. Ulmer's "The Object of Post-Criticism" has a section dealing with allegory also. See Ulmer's essay in The Anti-Aesthetic: Essays on Postmodern Culture, ed. Hal Foster, pp. 83-110.

25 Stephen Melville, "Notes on the Reemergence of Allegory, the Forgetting of Modernism, the Necessity of Rhetoric, and the Conditions of Publicity in Art and Criticism," October 19 (Winter 1981), p. 59.

26 Gadamer, Truth and Method, trans. Garrett Barden and John Cumming (New York: Seabury, 1973), p. 65.

27 Bruns, Inventions: Writing, Textuality, and Understanding in Literary History (New Haven, 1982), p. 6. 
28 Franz Kafka, "In the Penal Colony," in The Penal Colony: Stories and Short Pieces, trans. Willa and Edwin Muir (New York, 1948), p. 202.

29 Owens, "The Allegorical Impulse," p. 70.

30 For more on Icarus, see Joseph Leo Korner's Die Suche nach dem Labyrinth (Frankfurt, 1983).

31 Theodor Adorno, Minima Moralia: Reflections from Damaged Life, trans. E.F.N. Jephcott (London, 1974), p. 115.

32 Gadamer, Relevance of the Beautrful, p. 64.

33 Pauline Kael, Review of Brazil, The New Yorker (February 10, 1986), p. 106.

34 Television sets are everywhere in Brazil. For example, the workers at the Department of Records use their computer terminals as television sets, and one of the films they watch is Casablanca, a film about people trying to escape from a state, but who lack the proper papers. Having the proper papers is a major problem for characters in Brazil, especially for Jill Layton when she tries to reclaim Mr. Buttle's body. For more about Casablanca as a precursor to postmodernist collage, see Umberto Eco, "Casablanca: Cult Movies and Intertextual Collage" in Travels in Hyperreality (New York, 1986), pp. 197-211.

35 See Leslie Bennetts, "How Terry Gilliam Found a Happy Ending for Brazil," The New York Times (January 19, 1986), p. 16 of "Arts and Entertainment" section.

36 Vicki Hearne, Adam's Task: Calling Animals by Name (New York, 1986), p. 135.

37 Blanchot, The Writing of the Disaster, trans. Ann Smock (Lincoln, 1986), p. 1.

38 For further information on Eisenstein, see David A. Cook, A History of Narrative Film, pp. 142-181. Cook also includes reproductions of the Odessa steps sequence and the "masks of the gods" montage.

39 See Juergen Habermas, Communication and the Evolution of Society, trans. Thomas McCarthy (Boston, 1979), especially the chapters "What Is Universal Pragmatics?" and "Historical Materialism and the Development of Normative Structures." Also, his essay "The Entwinement of Myth and Enlightenment: Re-reading Dialectic of Enlightenment" addresses the issue of the deconstruction of truth, which stems, in part, from a post-structuralist and postmodernist attraction to Nietzsche. Habermas writes, "If thought can no longer operate in the realms of truth and validity claims, then analysis and critique lose their meaning," New German Critique 26 (Summer 1982), p. 27. A direct response to postmodernism appears in Habermas' "Modernity and Postmodernity," New German Critique 22 (Winter 1981), pp. 3-14.

40 Jean-Francois Lyotard, The Postmodern Condition: A Report on Knowledge, trans. Geoff Bennington and Brian Massumi (Minneapolis, 1984), p. 82.

On the death of the social, see Arthur Kroker and David Cook, "Postmodernism and the Death of the Social," in The Postmodern Scene: Excremental Culture and Hyper-Aesthetics (New York, 1986), pp. 168-242.

41 Felix Guattari, “The Postmodern Dead End," Flash Art 128 (May/June 1986), p. 40. This is a short but powerful critique of Lyotard and postmodernism in general.

42 Kael, p. 110.

43 Lyotard, p. 67.

44 Gadamer, Reason in the Age of Science, trans. Frederick Lawrence (Cambridge: MIT Press, 1981), p. 73.

45 Gadamer, Reason in the Age of Science, p. 74.

46 The impetus for the reading presented here comes, in part, from Geoff Waite's "Lenin in Las Meninas: An Essay in Historical-Materialist Vision," History and Theory 25 (1986), pp. 248-285. 